THE INTERNATIONAL

REVIEW OF RESEARCH IN

OPEN AND DISTANCE LEARNING

\title{
Development and Validation of the Online Student Connectedness Survey (OSCS)
}

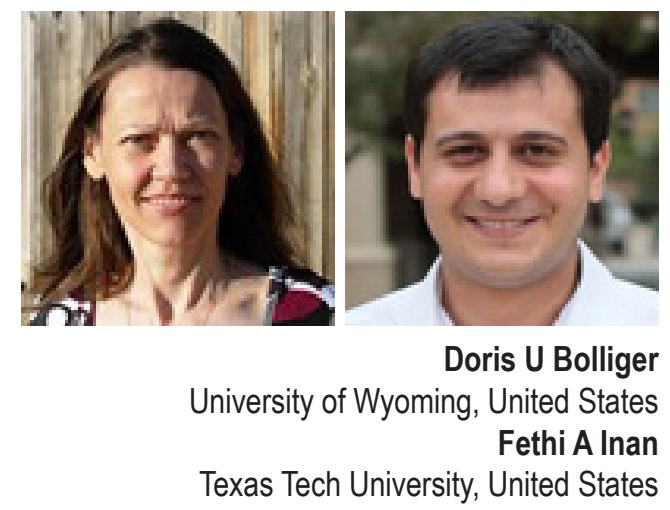

\section{Abstract}

With the growth of online courses and programs in higher education, considerable concerns emerge about student feelings of isolation and disconnectedness in the online learning environment. A research study was conducted to develop and validate an instrument that can be used to measure perceptions of connectedness of students enrolled in online programs or certification programs in higher education. The instrument consists of 25 items and has four scales: (a) community, (b) comfort, (c) facilitation, and (d) interaction and collaboration. One hundred and forty-six online learners who were enrolled in courses at a Turkish university completed the online questionnaire. Results of a factor and reliability analysis confirmed that the instrument is a valid and reliable measure of students' perceived connectedness in an online certificate program.

Keywords: Connectedness; isolation; learning community; online learning; social presence; higher education 


\section{Introduction}

The number of students who enroll in online courses offered by institutions of higher education in the United States has seen a dramatic growth over the past years. In fall 2008, 4.6 million students were enrolled in at least one online course; this marked a $17 \%$ increase from the number reported the previous year and was much higher than the $1.2 \%$ increase in higher education student body growth (Allen \& Seaman, 2010b). The growth continued in the fall of 2009 when the number of online students enrolled in online courses increased by almost 1 million - to 5.6 million - which marks a 21\% increase. During that time almost $30 \%$ of students in higher education took one online course. The growth rate for enrollment in online courses is not expected to drop off in the foreseeable future (Allen \& Seaman, 2010a). Similar to the U.S., the demand for online learning has increased worldwide (Demiray, 2010). Turkey, a country with a population of over 74 million, is considered a developing nation and faces several challenges. The country experienced a high increase in population in recent years, and approximately half of the population was under the age of 29 in 2011. The unemployment rate was $9.8 \%$ in 2011 but the unemployment rate for youth was much higher (18.4\%) (Turkish Statistical Institute, 2011).

Turkish universities served 3 million students in 2010 (Akguner, 2011). According to Yamamoto and Aydin (2010), the country has had high demand for opportunities in higher education and has experienced growth in online learning. In order to address the demand, Turkish higher education institutions have started offering more online courses and programs (Askar, 2009; Gursoy, 2005). For example, Anadolu University, one of the country's larger institutions, has 930,000 students enrolled in distance education offerings (Anadolu University, 2010).

There are several advantages of enrolling in online courses such as convenience, flexibility, and accessibility. Online students can easily access programs and experts without the need for relocation. As the courses are accessible from anywhere, students can structure their study time around other job or family-related responsibilities. Other possible advantages are streamlined courses; condensed, accelerated degree programs; diversity of peer groups; student-centered teaching approaches; and integration of innovative instructional technologies (Belanger \& Jordan, 2000; Hara \& Kling, 2000; Moore \& Kearsley, 1996). However, there are several challenges with online learning due to limited face-to-face personal interaction between students and instructors. Many sources attribute high student attrition in online courses to the lack of interaction between participants in courses taught in the distance education environment (Carr, 2000). They believe that isolation and disconnectedness of students in the online environment are two main factors in student dropout (Angelino, Williams, \& Natvig, 2007; Kanuka \& Jugdev, 2006). 


\section{Literature Review}

\section{The Social Dimension in Online Programs}

Researchers suggest that students in distance learning programs should be socially and academically integrated in order to provide meaningful learning experiences (Kanuka \& Jugdev, 2006). Shin (2003) reports that "the perceptions of psychological presence a distance student holds on the part of teachers, student peers, and the institution can be significant predictors of their success in distance learning" (p. 79). Yet not much attention has been given to the academic integration of students in distance programs. In one study, researchers concluded students had limited "opportunities for connecting to the larger community outside of what is provided in individual courses" (Exter, Korkmaz, Harlin, \& Bichelmeyer, 2009, p. 190). Angelino et al. (2007) point out the importance of the formation of "relationships with cohorts" (p. 8). Furthermore, Shin (2003) supports the notion that interaction between peers is important to online students and suggests that "the psychological presence of peer students can also bring a positive effect on various aspects of distance learning” (p. 8o). Shin's findings show that there was a statistically significant relationship between peer presence and student satisfaction and persistence.

Students in distance education may experience limited contact with academic staff at the university and department which can contribute to a feeling of disconnectedness. Exter et al. (2009) found distant learners did not participate as often in departmental activities as residential students, and distance students "did not generally have any way to connect to faculty who do not teach their courses, especially fulltime professors on campus" (p. 190). Additionally, distance students had less frequent contact with their advisors compared to residential students. The importance of the relationship between teacher presence and students' learning achievement was confirmed by results in a study conducted by Shin (2003). Quality student-teacher relationships and informal contact in a campus-based learning environment have been tied to higher student achievement and 'college outcomes' in the literature (Pascarella, 1980).

\section{Isolation and Connectedness}

Connectedness is the sense of belonging and acceptance. It refers to a person's belief that a relationship exists between him or her and at least one other individual. When individuals feel connected they feel less isolation (Lee \& Robbins, 1998; Rovai, 2002b; Shin, 2003). However, when students feel isolated, they may feel alone or disconnected from their social world. The impact of social isolation and connectedness in online courses is widely documented and many researchers argue that student isolation is one of the major problems for online learners (Kanuka \& Jugdev, 2006; Haythonthwaite, Kazmer, Robins, \& Shoemaker, 2000; Motteram \& Forrester, 2005; Rovai, 2002a; Shaw \& Polovina, 1999; Shieh, Gummer, \& Niess, 2008; Wegerif, 1998). For example, Lee and Robbins (1998) asserted that "people with high levels of connectedness are better able to manage their own needs and emotions through cognitive processes" (p. 338). Those individuals who feel connected are more willing and able to engage with others and participate in activities. Zembylas, The- 
odorou, and Pavlakis (2008), who investigated emotions of 92 online learners in a qualitative study, found that one of the major categories associated with negative emotions was loneliness and isolation. Students used words such as alone, desperation, hopelessness, distress, stress, and anxiety to describe their states of emotion in diary entries, interviews, final reports, phone conversations, and e-mails.

According to Stelzer and Vogelzangs (1994) isolation has two dimensions. These dimensions are physiological (physical and temporal) and psychological. Distance education students experience physiological isolation because they are physically separated by space and/or time. Social constructivists believe that learning is a social process. These beliefs are based on Vygotsky's $(1934,1962,1978)$ sociocultural theory which emphasized that cognitive development and learning takes place through communication and social interaction with others. But the Internet can be a medium of social isolation for some (Bibeau, 2001). Shin (2003) argues that "psychological distance is more important than physical distance" (p. 69). Terms such as human contact, interaction, and relationship have been associated with psychological distance (Shin, 2003). Interpersonal contact can be diminished in the online environment because most interaction and communication in which online learners engage is via computer-mediated communication (Aragon, 2003). Therefore, online teaching and learning can result in feelings of psychological isolation, sense of loneliness, or disconnectedness according to researchers (Motteram \& Forrester, 2005; Rovai, 2002a). However, researchers concluded students were positive about the use of computer-mediated communication and that those technologies helped combat isolation to a degree (Johnson \& Huff, 2000).

\section{Factors Pertaining to Student Connectedness}

\section{Community and social presence.}

Wegerif (1998) points out learners who do not feel part of a community "are on their own, likely to be anxious, defensive and unwilling to take the risks involved in learning" (p. 48). Online courses and programs have become more prevalent in higher education; therefore, online learners' sense of community is an important consideration (Rovai, 2002a). A learning community is defined as "groups of people engaged in intellectual interaction for the purpose of learning" (Cross, 1998, p. 4). McMillan and Chavis (1986) include four elements in their definition of sense of community: (a) membership, (b) influence, (c) integration and fulfillment of needs, and (d) shared emotional connection. The authors propose that in essence it is "a feeling that members have of belonging, a feeling that members matter to one another and to the group, and a shared faith that members' needs will be met through their commitment to be together" (p. 9). Rovai (2002a) identifies trust as an important characteristic of a community and stipulates that learners in strong learning communities feel connected.

The physical separation of online learners can reduce their sense of community (Rovai, 2002a). In order to combat student isolation, individuals suggest the integration of learn- 
ing communities in online courses (Bibeau, 2001; DiRamio \& Wolveton, 2006; Northrup, 2002; Palloff \& Pratt, 2007). Northrup (2002) found the majority of research participants agreed that it is important to create a community in online courses. There have been positive outcomes for students in learning communities (Haythornthwaite et al., 2000). DiRamio and Wolverton (2006) imply that the integration of online communities in the online environment can reduce student dropout rates and "can help meet the quality challenge" (p. 111). Online communities, however, must be fostered in order to be sustainable and successful (Palloff \& Pratt, 2007) and are not the answer to all challenges. Some students do not feel part of a community in online courses (Motteram \& Forrester, 2005). Other students may feel part of a community but may still experience high levels of isolation because they have limited opportunities to participate in those learning communities. While many students' feeling of community contributes to student satisfaction, not all students expect, need, or value a sense of community in online courses according to Drouin (2008).

The community of inquiry model (Rourke, Anderson, Garrison, \& Archer, 1999) is based on the belief that "deep and meaningful learning takes place in a community of inquiry" ( (2) that consists of instructors and learners. The model includes three independent important elements or types of presences: social, teaching, and cognitive. According to Shin (2003), presence "refers to the degree to which a distance student perceives the availability of, and connectedness with, people in his/her educational setting” (p. 71). Social presence, according to Short, Williams, and Christie (1976) contributes to the feeling of intimacy. Social presence is considered an important factor in student satisfaction and success (Bibeau, 2001; Swan \& Shih, 2005). Teachers create social presence so that learners can feel at ease in the learning environment and feel comfortable interacting with their peers and the instructor (Aragon, 2003). Tu (2002) confirmed several factors that influence perceived student levels of social presence: social context, privacy, online communication, and interaction.

Individuals who feel socially connected believe that they have close relationships with others (Lee \& Robbins, 1998). Research on interpersonal relationships in distance education environments are limited (Shin, 2003). However, it is possible that distance students have fewer opportunities to form close working relationships with program faculty, advisors, or peers. Furthermore, establishing educational relationships with learners "is more difficult when using computer-mediated conferencing” (Wikeley \& Muschamp, 2004, p. 138). When individuals do not feel connected, they may experience loneliness, an emotional distressing condition based on individuals' perceptions of isolation from or rejection by others and the lack of social networks and other support systems. Persons can experience loneliness when their relationships with others do not measure up in terms of anticipated or needed levels of quality. Loneliness is complex and can lead to anxiety and depression (McWirther, 1990).

\section{Comfort.}

Comfort is defined as experiencing contentment and security, and comfort with either integrated technologies or the learning environment is mentioned by researchers as an important aspect for distance students (Aragon, 2003; Haythornwaite et al., 2000; Kanuka 
\& Jugdev, 2006; Shin, 2003; Tu \& McIsaac, 2002; Wikeley \& Muschamp, 2004). Departments and instructors need to create safe learning environments (Stelzer \& Vogelzangs, 1994) in which learners feel comfortable and are encouraged to participate without fear of persecution. When students do not feel comfortable or safe in the learning environment, they are more likely to limit their interactions with an instructor and peers or less likely to ask for support (Shin, 2003); this can result in missed learning opportunities.

\section{Facilitation of learning.}

Instructors are central in creating learning communities and establishing teaching presence (Rouke et al., 1999). Shea, Li, and Pickett (2006) found a positive relationship between students' perceived learning and community and teaching presence. Swan and Shih (2005) found that teaching presence may be even more important than social presence. Young (2006) measured effective online teaching and found that one important element of good online teaching is the effective facilitation of a course. "The instructor's role and responsibilities in an online course involve carefully designed, primarily written communications with the learners" (p. 73). Therefore, instructors need to ensure that students have the opportunity to communicate, interact, and collaborate with course participants. "Online communication between distance students is purported by some authors as lessening student's feelings of isolation" (Motteram \& Forrester, 2005, p. 283).

Aragon (2003) believes that the use of formal titles creates a distance between students and instructors, hence he suggests giving students options in how to address the instructor. Tu and McIsaac (2002) found "the level of formality influenced the students' willingness to respond" (p. 144) in an online graduate-level course because participants felt closer to one another due to the fact that the psychological distance was reduced. Rovai (2003) who investigated relationships between communication styles, community, and learning styles in online courses found "friendly and open communication styles correlated with connectedness" (p. 360). Norton $(1983,1986)$ developed a communicator style inventory. He includes several styles such as the open and friendly style. Open communicators share accurate information about themselves by using a conversational and an approachable tone (Johnson \& Evans, 1997; Norton, 1983). They are willing to share their thoughts and emotions openly. Friendly communicators are tactful; they tend to encourage individuals and acknowledge others' contributions (Johnson \& Evans, 1997).

Engaged learners are active participants in the learning process. Involved learners actively participate in their construction of knowledge and acquisition of skills. By actively engaging students in an active learning environment we encourage them "to read, speak, listen, think deeply, and to write" (Berge, 2002, p. 184). Learners engage in the construction of meaningful or relevant knowledge and skills through collaboration, interaction, and individual activities (Jonassen, Howland, Marra, \& Crismond, 2008). In most instances, learners should not be engaged with course content in isolation. Rather, they should be engaged in creating meaning by interacting with peers and the instructor and collaborating with classmates. Walker and Fraser (2005) created an instrument to assess distance education learning environments in higher education and included a subscale on interaction and col- 
laboration.

\section{Collaboration and interaction.}

Projects that require students to work together collaboratively can reduce levels of student isolation (Wikeley \& Muschamp, 2004). Interaction is a two-way communication process that involves two or more individuals (Berge, 2002). By using the process of interaction, data, information, and ideas are manipulated and enhanced, and transformed into newly acquired knowledge.

One important factor in student satisfaction and learning in the online environment is interaction (Bolliger \& Martindale, 2004). Moore (1989) classifies interaction into three categories: interaction with content, interaction with instructors, and interaction with peers. Social interaction is an essential component of learning in the online environment (Garrison, 2000; Rovai, 2002a). Students need to process information provided via communication in order to generate their own knowledge. At times, students can accomplish the transformation from information to knowledge by themselves, and sometimes they require assistance from instructors or peers. Brown and Duguid (2000) write "the resources for learning lie not simply in information, but in the practice that allows people to make sense of and use that information and the practitioners who know how to use that information" (p. 133).

\section{Purpose of the Study}

Although the importance of the isolation and connectedness in online learning has been acknowledged by previous research, there have only been a limited number of initiatives to design and develop instruments to measure the underlying concept of student connectedness. Unfortunately, those existing instruments do not specifically measure connectedness of students enrolled in online degree or certificate programs and are not applicable to different student populations (e.g., undergraduates, postgraduates, etc). A literature review yielded three validated instruments that attempt to measure factors closely related to community, social presence, or connectedness in specific settings or targeted specific student populations. Rovai's (2002a) Classroom Community Scale (CCS) has been a frequently used instrument that includes two subscales: connectedness and learning. The instrument, however, aims to measure only students' perceptions of the sense of community in a learning environment in broad scale. Barnard-Brak and Shui (2010) tested the CCS's psychometric properties with students enrolled in a blended undergraduate course and point out that its use may be limited to a population of graduate students; the instrument's construct validity was not supported in their review.

Another instrument, the Social Presence and Privacy Questionnaire, was developed by Tu (2002) to assess social presence in computer-mediated communication. The author proposed that social presence includes three constructs: interactivity and online communication, social context, and online privacy. Some of the elements identified by Tu may be related to students' sense of connectedness; however, those elements are not specifically targeted to measure connectedness. 
An instrument developed by Terrell, Snyder, and Dringus (2009) measures sense of connectedness of doctoral students who are in the dissertation writing phase in order to identify students who may consider dropping out of the program. The validated scale includes items pertaining to two elements: learners' "sense of community and research competency" (p. 113). However, the need of doctoral students for connectedness with faculty and peers is much different from students who do not seek terminal degrees. Doctoral students are engaged in independent research and need faculty mentors who not only train, support, advise, sponsor, and encourage them but who provide opportunities for networking and funding (Walker, Golde, Jones, Bueschel, \& Hutchings, 2008).

Therefore, it was the purpose of this research study to identify and confirm factors specifically influencing student connectedness in online programs in higher education and to develop and validate a reliable instrument to measure perceived feelings of connectedness of students enrolled in online degree or certificate programs.

\section{Methodology}

\section{Initial Development of the OSCS}

The initial item development process included (a) an in-depth review of the literature, (b) an expert-panel review, and (c) a pilot questionnaire. Items were developed based on the literature associated with students' academic environments and sense of isolation. The literature suggests four important elements are associated with student connectedness: (a) comfort, (b) community, (c) facilitation, and (d) interaction and collaboration. Initially, 78 Likert-scale items were developed to address the identified dimensions and elements. Five slightly modified items from the interaction and collaboration subscale developed by Walker and Fraser (2005) were included after obtaining permission from the authors. The final version of the instrument consists of 25 Likert-scale items ranging from 1, strongly disagree to 5, strongly agree.

\section{Validity and reliability.}

In order to ensure the construct validity of the original survey, the questionnaire was reviewed by a panel of experts involved in distance education and instructional technology at three public research universities in the United States. Four reviewers, three faculty members, and one distance education administrator with extensive experience in the delivery of online courses and programs were invited to evaluate all Likert-scale items on their representation of the construct they were purported to measure and on their clarity. Experts were provided with scale items, operational definitions, and instructions on rating the items. Reviewers were instructed to (a) indicate the items' relevance and to rate the degree to which each item corresponded with the construct and subconstruct; (b) evaluate the clarity of each item; (c) recommend changes for any items they felt were unclear; (d) recommend any addition or deletion of items; and (e) evaluate the structure and definition of each construct and subconstruct. The expert review resulted in the revision, deletion, and addition of several items. Several closely related items were removed in order to reduce 
the number of scale items before administering the survey to students in a pilot study.

The revised version of the scale included 48 Likert-scale items. After the validation study, items with high factor loadings were selected for the administration to students in this research study. The final version of the instrument included 25 items. An internal reliability coefficient was calculated for the instrument and its subscales after the questionnaire was administered during the study to students enrolled in three online programs (education, business, and nursing) at a research university in the western United States. The instrument's reliability was found to be very high $(a=.98)$.

\section{Turkish Version of the OSCS}

The English version of the instrument was translated into Turkish by a team of faculty and graduate students including one professor, three online instructors, and three graduate students who have high competency in both the English and Turkish languages. The team worked collaboratively to ensure that the instrument had semantic equivalence across languages and conceptual equivalence across cultures (Cha, Kim, \& Erlen, 2007). The developed Turkish version of the instrument was then distributed to one Turkish professional in the field of distance education to gather his views regarding the content validity (e.g., evaluating the item clarity and the relevance of items) (Ozkok, Walker, \& Buyukozturk, 2009).

\section{Setting and Participants}

After the development process, the finalized Turkish version of the instrument was administered to students enrolled in an online information technologies certificate program offered by a computer engineering department at a university in Turkey in spring 2010. The certificate consists of eight sequenced online courses that are completed in four semesters. Students are grouped into cohorts and can complete the certificate in nine months. The certificate attracts not only currently enrolled university students (at the undergraduate and graduate level) but also postgraduates who desire to learn about computer engineering and information technology.

At the beginning of the semester, 175 students were enrolled in two courses that utilize asynchronous and synchronous delivery methods. One hundred and forty-six individuals (83\%) completed the online questionnaire. Over 70\% of respondents were male (73.3\%), and the majority (59.2\%) was classified as current undergraduate or graduate students, whereas $40.8 \%$ had already graduated from college. Their ages ranged from 19 to $47(M=$ 27.62). Half of the students were currently employed (53.4\%) and resided in the capitol city (50.4\%). Only 10.3\% had previously taken an online course.

\section{Data Analysis}

As a preliminary exploration of the factor, a principal components factor analysis with oblimin rotation was performed on the 25 questionnaire items. Prior to conducting the analysis, assumptions (adequacy of sample size, factorability, presence of outliers, linearity, and multicollinearity) were checked. In order to interpret factor structure, the pattern matrix and structure matrix were examined for item loadings to determine the number of factors 
to retain; several methods including Kaiser's (1960) eignvalues greater than one rule, Cattel's (1966) scree test, total variance, and residuals (the difference between the empirical and reproduced correlations) were utilized (Mertler \& Vannatta, 2010; Stevens, 2010).

\section{Sample size and factorability.}

The data set included 146 completed response sets. This is considered adequate because all communalities were greater than .60 , items per factor ratio was about 5:1, and all factor loadings were above .60 in absolute value (Stevens, 2010). Bartlett's test of sphericity (Bartlett, 1950) and Kaiser-Myer-Olkin measure (Mertler \& Vannatta, 2010) was checked to see if the data were appropriate for a factor analysis. Both the Kaiser-Myer-Olkin measure of sampling adequacy (.935) and the Bartlett's test of sphericity $\left(\chi^{2}=4694.87, p=.000\right)$ suggested that the dataset was suitable for factor analysis. Furthermore, Kaiser's measure of sampling adequacy (MSA) for all items was greater than .90 which is considered very good (Pett, Lackey, \& Sullivan, 2003).

\section{Outliers.}

The data was screened for univariate and multivariate outliers. Initially, an examination of $z$ scores revealed two potential outliers within the range of $z \pm 3.00$. Leverage values were examined to detect multivariate outliers. Thirteen additional possible outliers were detected by using the cutoff value (.37) calculated by the formula provided by Tabachnick and Fidell (2007). However, the examination of those cases did not indicate any obvious reasons to exclude those data sets from the analysis. Factor analyses were performed with and without outliers to see whether those data sets significantly impacted the results. Examination of factor structure, communalities, and percentage of variance explained clearly indicated that results were consistent with or without those outliers. Therefore, all data sets were included in the analysis.

\section{Linearity and multicollinearity.}

In order to examine for linearity, several bivariate scatterplots were generated and examined. A scatterplot matrix revealed fairly normal distributions and linear relationships among variables. In order to determine if multicollinearity existed, squared multiple correlations (SMCs) for each variable were examined. Only one of the SMC values (.903) was close to 1 . The correlation coefficients among variables were high but only two of the correlations were just above .90 .

\section{Results}

\section{Factor Analysis}

The construct validity was examined using a confirmatory analysis with oblim rotation. An initial examination revealed four dimensions with eigenvalues greater than 1 . Inspection of 
other criteria including variance, scree plot (see Figure 1), and residuals also suggest that four components should be investigated. Thus, a principal components factor analysis with oblimin rotation was conducted to retain four components.

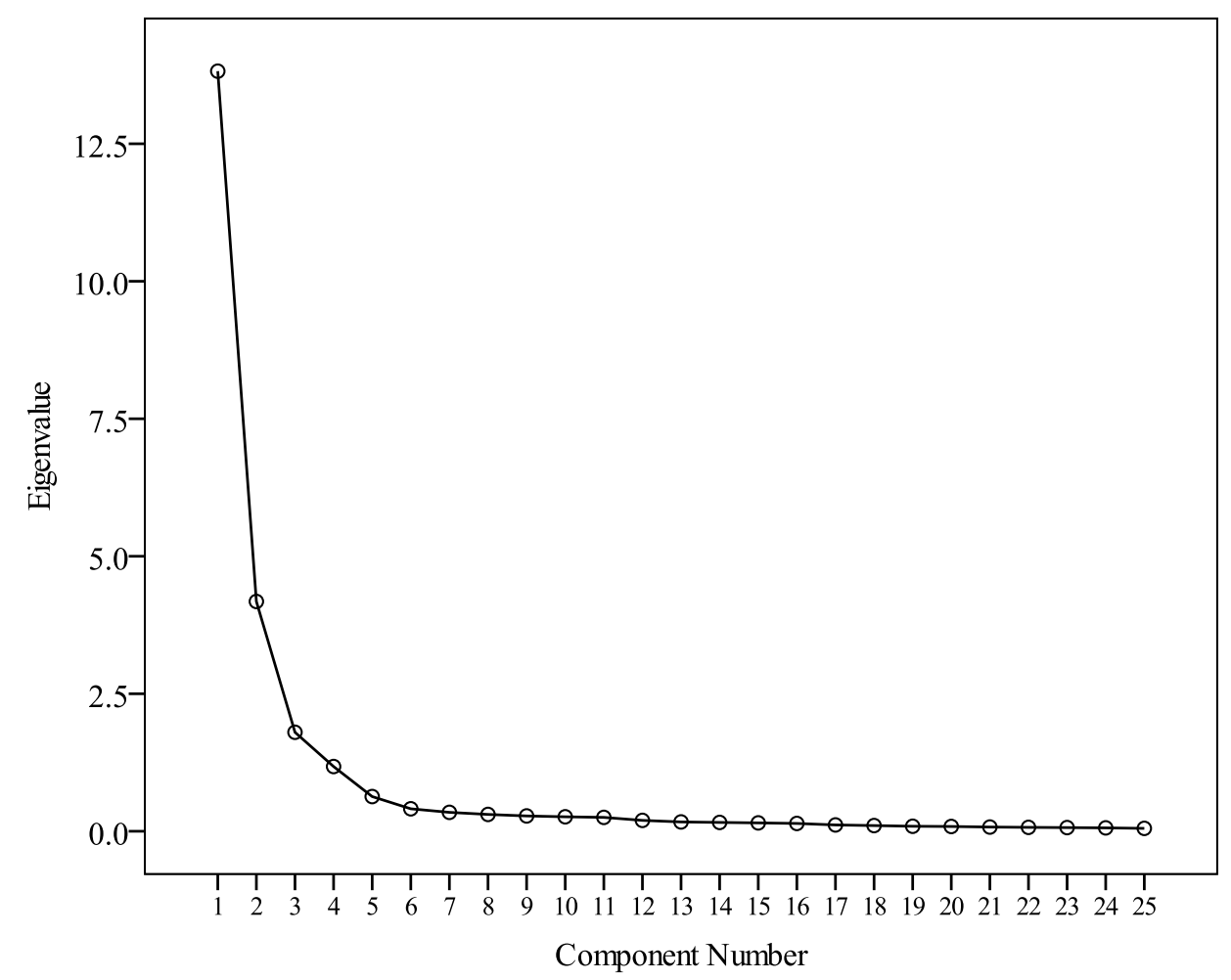

Figure 1. Scree plot.

The four factor solution explained $83.95 \%$ of the variance. The factor labels proposed by researchers suited the extracted factors and, therefore, were retained. The examination of the pattern matrix suggested the loading of eight items for comfort, six items for social community, six items for facilitation, and five items for collaboration and interaction scales. Loadings of variables on factors, communalities, and percent of variance are shown in Table 1. The pattern matrix loadings exhibited a simple structure; all items had loadings in excess of .50. Variables were ordered and grouped by the size of loading. Loadings less than .5 were suppressed (Stevens, 2010). 
Table 1

Items, Factor Loadings, and Communalities $(N=146)$

\section{Constructs}

\begin{tabular}{|c|c|c|c|c|}
\hline Scales/Items & 1 & 2 & 3 & 4 \\
\hline \multicolumn{5}{|l|}{ Comfort } \\
\hline Q1. If I need to, I will ask for help from my classmates. & 0.95 & & & \\
\hline $\begin{array}{l}\text { Q2. I feel comfortable expressing my opinions and feelings } \\
\text { in online courses. }\end{array}$ & 0.91 & & & \\
\hline Q3. I feel comfortable introducing myself in online courses. & 0.91 & & & \\
\hline Q4. I can effectively communicate in online courses. & 0.90 & & & \\
\hline $\begin{array}{l}\text { Q5. I feel comfortable asking other students in online cours- } \\
\text { es for help. }\end{array}$ & 0.90 & & & \\
\hline $\begin{array}{l}\text { Q6. I have no difficulties with expressing my thoughts in my } \\
\text { online courses. }\end{array}$ & 0.88 & & & \\
\hline $\begin{array}{l}\text { Q7. I feel my instructors have created a safe online environ- } \\
\text { ment in which I can freely express myself. }\end{array}$ & 0.87 & & & \\
\hline $\begin{array}{l}\text { Q8. I feel comfortable in the online learning environment } \\
\text { provided by my program. }\end{array}$ & 0.72 & & & \\
\hline
\end{tabular}

Community

Q9. I feel emotionally attached to other students in my online courses. 0.89

Q10. I spend a lot of time with my online course peers.

0.84

Q11. My peers have gotten to know me quite well in my online courses. 0.83

Q12. I feel that students in my online courses depend on me. 0.77

Q13. I can easily make acquaintances in my online courses. 0.73

Q14. I have gotten to know some of the faculty members and classmates well.

Facilitation

Q15. Instructors integrate collaboration tools (e.g., chat rooms, wikis, and group areas) into online course activities.

Q16. In my online courses, instructors promote interaction between learners.

0.85

Q17. Instructors promote collaboration between students in my online courses. 


\begin{tabular}{ll}
\hline Q18. My online instructors are responsive to my questions. & 0.75 \\
\hline Q19. I receive frequent feedback from my online instructors. & 0.70 \\
\hline Q20. My instructors participate in online discussions. & 0.65 \\
\hline Interaction and Collaboration & \\
\hline Q21. I relate my work to others' work in my online courses. & 0.89 \\
\hline $\begin{array}{l}\text { Q22. I discuss my ideas with other students in my online } \\
\text { courses. }\end{array}$ & 0.85 \\
\hline Q23. I collaborate with other students in my online courses. & 0.85 \\
\hline Q24. I work with others in my online courses. & 0.84 \\
\hline Q25. I share information with other students in my online & \\
courses. & \\
\hline
\end{tabular}

In order to determine the instrument's internal consistency reliability, the Cronbach alpha coefficient was calculated. The whole survey includes 25 items and its reliability was high (.97). Similarly, reliability of subscales was high for all factors: comfort (.97), community (.96), facilitation (.94), and interaction and collaboration (.97). Table 2 displays the means and standard deviations for the survey items. Standard deviations are relatively minor.

Table 2

Mean Scores and Standard Deviations

\begin{tabular}{lll}
\hline & \multicolumn{2}{c}{ Comfort } \\
\cline { 2 - 3 } Item & $M$ & $S D$ \\
\hline 1 & 3.77 & 1.20 \\
2 & 3.81 & \\
3 & & 1.12 \\
4 & 3.68 & 1.20 \\
5 & 3.78 & 1.12 \\
& & \\
& 3.90 & 1.12
\end{tabular}




$\begin{array}{lll}6 & 3.81 & 1.15 \\ 7 & 3.85 & 1.14 \\ 8 & 3.81 & 1.16\end{array}$

\begin{tabular}{lll} 
& \multicolumn{2}{c}{ Community } \\
\cline { 2 - 3 } Item & $M$ & $S D$ \\
\hline & & \\
9 & 2.99 & 1.27 \\
10 & & 1.23 \\
11 & 2.45 & 1.21 \\
12 & 2.86 & 1.30 \\
13 & & 1.30 \\
14 & 2.29 & 1.32
\end{tabular}

Facilitation

\begin{tabular}{lll}
\cline { 2 - 2 } & \\
Item & $M$ & $S D$ \\
\hline
\end{tabular}

15

3.28

1.19

16

$3 \cdot 33$

1.15

17

3.62

1.13 
18

19

20

\begin{tabular}{llc}
\hline & \multicolumn{2}{c}{ Interaction and Collaboration } \\
\cline { 2 - 3 } Item & $M$ & $S D$ \\
\hline & & \\
21 & 3.05 & 1.28 \\
22 & 3.14 & 1.25 \\
23 & 3.25 & 1.18 \\
24 & 3.32 & 1.19 \\
25 & 3.23 & 1.23 \\
\hline
\end{tabular}

1.12

1.05
1.11
3.58 
valid and reliable measure of student connectedness in online programs, it can be used in future studies to ascertain different levels of connectedness. The instrument can be used to evaluate the effectiveness of planned instructional events and integrated strategies for fostering students' perceptions of connectedness in online degree or certificate programs and, if needed, assist in the revisions of online programs.

\section{Limitations}

Some limitations need to be pointed out. First, the geographical area was limited and participants were recruited from only one university. Second, all study participants were enrolled in courses in one subject area, computer engineering. The sample is somewhat unique because over 70\% were male. Therefore, the results should be interpreted with caution as their generalizability may be limited. Future research could include a replication of the study with the inclusion of multiple institutions and the solicitation of students with different majors.

\section{Acknowledgment}

The authors would like to thank all colleagues and students who contributed to this study. We are grateful to Scott Walker, Steven Crooks, Landra Rezabek, Larry Jansen, Erman Yukselturk, Fatih Ari, Ismahan Arslan-Ari, and Gul Durukan for their contributions and help during the instrument development process. 


\section{References}

Akguner, P. (2011, May 11). Turkey: Education market (Market Research Library). Washington, DC: United Sates Department of Commerce. Retrieved from http://www. buyusainfo.net/docs/x_678799.pdf

Allen, I. E., \& Seaman, J. (2010a, November). Class differences: Online education in the United States, 2010. Babson Park, MA: Babson Survey Research Group. Retrieved from http://www.usdla.org/assets/pdf_files/2010\%20Sloan-C\%20Report\%20 on\%20Online\%2oEducation\%2oEnrollment.pdf

Allen, I. E., \& Seaman, J. (2010b, January). Learning on demand: Online education in the United States, 2009. Babson Park, MA: Babson Survey Research Group. Retrieved from http://sloanconsortium.org/sites/default/files/pages/learningondemand-7. pdf

Anadolu University. (2010, December 30). About. Retrieved from http://www.anadolu. edu.tr/en/universitemiz/hakkinda.aspx

Angelino, L. M., Williams, F. K., \& Natvig, D. (2007). Strategies to engage online students and reduce attrition rates. Journal of Educators Online, 4(2), 1-14.

Aragon, S. R. (2003). Creating social presence in online environments. In S. R. Aragon (Ed.), Facilitating learning in online environments (pp. 57-68). San Francisco: Jossey-Bass.

Askar, P. (2009). Distance education in Turkey. In P. L. Rogers et al. (Eds.), Encyclopedia of distance learning (2nd ed., pp. 671-675). Hershey, PA: Idea Group Reference.

Barnard-Brak, L., \& Shiu, W. (2010). Classroom community scale in the blended learning environment: A psychometric review. International Journal on E-Learning, 9(3), 303-311.

Bartlett, M. S. (1950). Tests of significance in factor analysis. British Journal of Statistical Psychology, 3, 77-85.

Belanger, F., \& Jordan, D. H. (2000). Evaluation and implementation of distance learning: Technologies, tools and techniques. Hershey, PA: Idea Publishing Group.

Berge, Z. L. (2002). Active, interactive, and reflective elearning. The Quarterly Review of Distance Education, 3(2), 181-190.

Bibeau, S. (2001). Social presence, isolation and connectedness in online teaching and learning: From the literature to real life. Journal of Instruction Delivery Systems, 15(3), 35-39. 
Bolliger, D. U., \& Martindale, T. (2004). Key factors influencing student satisfaction with online courses. International Journal on E-Learning, 3(1), 61-67.

Brown, J. S., \& Duguid, P. (2000). Social life of information. Boston, MA: Harvard Business School Press.

Carr, S. (2000, February 11). As distance education comes of age, the challenge is keeping the students. Chronicle of Higher Education, 46(23), A39. Retrieved from Academic Search Premier database.

Cattell, R. B. (1966). The scree test for the number of factors. Multivariate Behavioral Research, 1(2), 245-276.

Cha, E. S., Kim, K. H., \& Erlen, J. A. (2007). Translation of scales in crosscultural research: issues and techniques. Journal of Advanced Nursing, 58(4), 386-395.

Cross, K. P. (1998). Why learning communities? Why now? About Campus, 3(3), 4-11. Retrieved from Academic Search Premier database.

Exter, M. E., Korkmaz, N., Harlin, N. M., \& Bichelmeyer, B. A. (2009). Sense of community within a fully online program: Perspective of graduate students. The Quarterly Review of Distance Education, 10(2), 177-194.

Demiray, U. (Ed.). (2010). e-Learning practices: Cases and challenges facing e-learning and national development: Institutional studies and practices, Vol. 1. Eskisehir, Turkey: Anadolu University. Retrieved from http://www.midasebook.com/dosyalar/FINAL_ELEARN_EBOOK_VOL1.pdf

DiRamio, D., \& Wolverton, M. (2006). Integrating learning communities and distance education: Possibility or pipedream? Innovative Higher Education, 31(2), 99-113.

Drouin, M. A. (2008). The relationship between students' perceived sense of community and satisfaction, achievement, and retention in online courses. Quarterly Review of Distance Education, 9(3), 267-284.

Garrison, R. (2000). Theoretical challenges for distance education in the 21st century: A shift from structural to transactional issues. International Review of Research in Open and Distance Learning, 1(1), 1-17.

Gursoy, H. (2005). A critical look at distance education in Turkey. In A. A. Carr-Chellman (Ed.), Global perspectives on e-learning: Rhetoric and reality (pp. 115-126).Thousand Oaks, CA: Sage.

Hara, N., \& Kling, R. (2000). Student distress in a Web-based distance education course. Information, Communication, and Society, 3(4), 557-579.

Haythornthwaite, C., Kazmer, M. M., Robins, J., \& Shoemaker, S. (2000). Community 
development among distance learners: Temporal and technological dimensions. Journal of Computer-Mediated Communication, 6(1). Retrieved from http:// jcmc.indiana.edu/vol6/issue1/haythornthwaite.html

Johnson, P. E., \& Evans, J. P. (1997). Power, communicator styles, and conflict management styles: A web of interpersonal constructs for the school principal. International Journal of Educational Reform, 6(1), 40-53.

Johnson, M. M., \& \& Huff, M. T. (2000). Students' use of computer-mediated communication in a distance education course. Research on Social Work Practice, 10(4), 519-532.

Jonassen, D. H., Howland, J., Marra, R. M., \& Crismond, D. P. (2008). Meaningful learning with technology (3rd ed.). Upper Saddle River, NJ: Pearson/Merrill Prentice Hall.

Kaiser, H. F. (1960). The application of electronic computers to factor analysis. Educational and Psychological Measurement, 20, 141-151.

Kanuka, H., \& Jugdev, K. (2006). Distance education MBA students: An investigation into the use of an orientation course to address academic and social integration issues. Open Learning, 21(2), 153-166.

Lee, R. M., \& Robbins, S. B. (1998). The relationship between social connectedness and anxiety, self-esteem, and social identity. Journal of Counseling Psychology, 45(3), 338-345.

McMillan, D. W., \& Chavis, D. M. (1986). Sense of community: A definition and theory. Journal of Community Psychology, 14(1), 6-23.

McWirther, B. T. (1990). Loneliness: A review of the current literature, with implications for counseling and research. Journal of Counseling and Development, 68(4), 417422.

Mertler, C. A., \& Vannatta, R. A. (2010). Advanced and multivariate statistical methods: Practical application and interpretation (4th ed.). Los Angeles, CA: Pyrczak.

Moore, M. G. (1989). Three types of interaction. The American Journal of Distance Education, 3(2). Retrieved from http://www.ajde.com/Contents/vol3_2.htm\#editorial

Moore, M. G., \& Kearsley, G. (1996). Distance education: A systems view. Belmont, CA: Wadsworth Publishing Company.

Motteram, G., \& Forrester, G. (2005). Becoming an online distance learner: What can be learned from students' experiences of induction to distance programmes. Distance Education, 26(3), 281-298. 
Northrup, P. T. (2002). Online learners' preferences for interaction. The Quarterly Review of Distance Education, 3(2), 219-226.

Norton, R. (1983). Communicator style: Theory, application, and measures. Beverly Hills, CA: Sage.

Norton, R. W. (1986). Communicator style in teaching: Giving good form to content. In J. M. Civikly (Ed.), Communicating in college classrooms (pp. 33-40). New Directions for Teaching and Learning, no. 26. San Francisco: Jossey-Bass.

Ozkok, A., Walker, S. L., \& Buyukozturk, S. (2009). Reliability and validity of a Turkish version of the DELES. Learning Environments Research, 12(3), 175-190.

Palloff, R. M., \& Pratt, K. (2007). Building online learning communities: Effective strategies for the virtual classroom (2nd ed.). San Francisco: Jossey-Bass.

Pascarella, E. T. (1980). Student-faculty informal contact and college outcomes. Review of Educational Research, 5o(4), 545-595.

Pett, M. A., Lackey, N. R., \& Sullivan, J. J. (2003). Making sense of factor analysis: The use of factor analysis for instrument development in health care research. Thousand Oaks, CA: Sage.

Rouke, L., Anderson, T., Garrison, D. R., \& Archer, W. (1999). Assessing social presence in asynchronous text-based computer conferencing. Journal of Distance Education, 14(2), 50-71.

Rovai, A. P. (2002a). Development of an instrument to measure classroom community. The Internet and Higher Education, 5(3), 197-211. doi:10.1016/S1096-7516(02)001021

Rovai, A. P. (2002b). Sense of community, perceived cognitive learning, and persistence in asynchronous learning networks. The Internet and Higher Education, 5(4), 319332. doi:10.1016/S1096-7516(02)oo130-6

Rovai, A. P. (2003). The relationship of communicator style, personality based learning style, and classroom community among online graduate students. The Internet and Higher Education, 6, 347-363. doi:10.1016/j.iheduc.2003.07.004

Shaw, S., \& Polovina, S. (1999). Practical experiences of, and lessons learnt from, Internet technologies in higher education. Educational Technology \& Society, 2(2). Retrieved from http://ifets.ieee.og/periodical/vol._3_99/stephen_shaw.html

Shea, P., Li, C. S., \& Pickett, A. (2006). A study of teaching presence and student sense of learning community in fully online and web-enhanced college courses. The Internet and Higher Education, 9(3), 175-190. 
Shieh, R. S., Gummer, E., \& Niess, M. (2008). Perspectives of the instructor and the students. TechTrends, 52(6), 61-68.

Shin, N. (2003). Transactional presence as a critical predictor of success in distance learning. Distance Education, 24(1), 69-86.

Short, J., Williams, E., \& Christie, B. (1976). The social psychology of telecommunications. New York: Wiley.

Stelzer, M, \& Vogelzangs, I. (1994). Isolation and motivation in on-line and distance learning courses. In B. Collins (Ed.), On-line and distance education courses: A reader. Enschede, Netherlands: University of Twente. Retrieved from http://projects.edte. utwente.nl/ism/Online/chap8/chap8.htm

Stevens, J. (2010). Applied multivariate statistics for the social sciences. Mahwah, NJ: Lawrence Erlbaum.

Swan, K., \& Shih, L. F. (2005). On the nature and development of social presence in online course discussions. Journal of Asynchronous Learning Network, 9(3), 115-136.

Tabachnick, B. G., \& Fidell, L. S. (2007). Using multivariate statistics (5th ed.). Boston, MA: Allyn and Bacon.

Terrell, S. R., Snyder, M. M., \& Dringus, L. P. (2009). The development, validation, and application of the Doctoral Student Connectedness Scale. The Internet and Higher Education, 12(2), 112-116. doi:10.1016/j.iheduc.2009.06.004

Tu, C. (2002). The measurement of social presence in an online learning environment. International Journal on E-Learning, 1(2), 34-45.

Tu, C., \& McIsaac, M. (2002). The relationship between social presence and interaction in online classes. The American Journal of Distance Education, 16(3), 131-150.

Turkish Statistical Institute. (2010). Welcome to Turkish Statistical Institute (TurkStat). Retrieved from http://www.turkstat.gov.tr

Vygotsky, L. S. (1962). Thought and language (E. Hanfmann \& G. Vakar [Eds.] Trans.). Cambridge, MA: The Massachusetts Institute of Technology. (Original work published 1934)

Vygotsky, L. S. (1978). Mind in society: The development of higher psychological processes. Cambridge, MA: Harvard University Press.

Walker, G. E., Golde, C. M., Jones, L., Bueschel, A. C., \& Hutchings, P. (2008). The formation of scholars: Rethinking doctoral education for the twenty-first century. The 
Carnegie Foundation for the Advancement of Teaching. San Francisco, CA: JosseyBass.

Walker, S. L., \& Fraser, B. J. (2005). Development and validation of an instrument for assessing distance education learning environments in higher education: The distance learning environments survey (DELES). Learning Environments Research, 8(3), 289-308. doi:10.1007/s10984-005-1568-3

Wegerif, R. (1998). The social dimensions of asynchronous learning networks. Journal of Asynchronous Learning Networks, 2(1), 34-49. Retrieved from http://www. sloan-c.org/publications/jaln/v2n1/pdf/v2n1_wegerif.pdf

Wikeley, F., \& Muschamp, Y. (2004). Pedagogical implications of working with doctoral students at a distance. Distance Education, 25(1), 125-142.

Young, S. (2006). Student views of effective online teaching in higher education. The American Journal of Distance Education, 20(2), 65-77.

Zembylas, M., Theodorou, M., \& Pavlakis, A. (2008). The role of emotion in the experience of online learning: Challenges and opportunities. Education Media International, 45(2), 107-117.

Yamamoto, G. T., \& Aydin, C. H. (2010). eLearning in Turkey: Past, present and future. In U. Demiray, L. Vainio, M. C. Sahin, G. Kurubacak, P. T. Lounaskorpi, S. R. Rao, \& C. Machado (Eds.), e-Learning practices: Volume II: Cases and challenges facing e-learning and national development: Institutional studies and practices (pp. 961-987). Retrieved from http://www.midasebook.com/dosyalar/FINAL_ELEARN_EBOOK_VOL2.pdf 


\section{Appendix: Online Student Connectedness Survey}

\section{Comfort}

English

1. I feel comfortable in the online learning environment provided by my program.

2. I feel my instructors have created a safe online environment in which I can freely express myself.

3. I feel comfortable asking other students in online courses for help.

4. I feel comfortable expressing my opinions and feelings in online courses.

5. I feel comfortable introducing myself in online courses.

6. If I need to, I will ask for help from my classmates.

7. I have no difficulties with expressing my thoughts in my online courses.

8. I can effectively communicate in online courses.

Turkish

1. Çevrimiçi ders ortamında kendimi rahat hissediyorum

2. Çevrimiçi ders ortamında kendimi özgürce ifade edebileceğimi düşünüyorum

3. Çevrimiçi derslerde diğer öğrencilerden rahatlıkla yardım isteyebilirim

4. Çevrimiçi derslerde duygu ve düşüncelerimi rahatlıkla ifade edebilirim

5. Çevrimiçi derslerde kendimi tanıtmaktan çekinmem

6. Çevrimiçi derslerde ihtiyacım olursa sınıf arkadaşlarımdan yardım istemekten çekinmem

7. Çevrimiçi derslerde fikirlerimi ifade ederken hiç zorluk çekmem

8. Çevrimiçi derslerde etkili biçimde iletişim kurabilirim 


\section{Community}

English

1. I have gotten to know some of the faculty members and classmates well.

2. I feel emotionally attached to other students in my online courses.

3. I can easily make acquaintances in my online courses.

4. I spend a lot of time with my online course peers.

5. My peers have gotten to know me quite well in my online courses.

6. I feel that students in my online courses depend on me.

Turkish

1. Çevrimiçi derslerde bazı öğretmen ve öğrencilerle yakınlık kurma firsatım oldu

2. Çevrimiçi derslerde diğer öğrencilerle aramda sıkı bir duygusal bağ oluştuğunu hissediyorum

3. Çevrimiçi derslerde kolaylıkla arkadaşlıklar edinebiliyorum

4. Çevrimiçi derslerde birlikte çalıştığım diğer öğrencilerle çokça zaman geçiriyorum

5. Çevrimiçi derslerde diğer öğrenciler beni tanıma firsatı buldular

6. Çevrimiçi derslerde diğer öğrencilerin bana güvendiğini hissediyorum

\section{Facilitation}

English

1. Instructors promote collaboration between students in my online courses.

2. Instructors integrate collaboration tools (e.g., chat rooms, wikis, and group areas) into online course activities.

3. My online instructors are responsive to my questions.

4. I receive frequent feedback from my online instructors.

5. My instructors participate in online discussions.

6. In my online courses, instructors promote interaction between learners. 
Turkish

1. Çevrimiçi öğretmenler öğrencilerin birlikte çalışmalarını istiyorlar

2. ̈̈̆gretmenler öğrencilerin birilikte çalışması için gerekli çevrimçi iletişim ve etkileşim araçlarını sağlıyorlar

3. Çevrimiçi öğretmenler benim her sorumu cevapliyorlar

4. Çevrimiçi öğretmenler düzenli olarak geri bildirim veriyorlar

5. Öğretmenler çevrimiçi tartışmalara sürekli katılıyorlar

6. Çevrimiçi öğretmenler öğrenciler arasında etkileşimi teşvik ediyorlar

\section{Interaction and Collaboration}

English

1. I work with others in my online courses.

2. I relate my work to others' work in my online courses.

3. I share information with other students in my online courses.

4. I discuss my ideas with other students in my online courses.

5. I collaborate with other students in my online courses.

Turkish

1. Çevrimiçi derslerde diğer öğrenciler ile birlikte ortak çalışma yaparım

2. Çevrimiçi derslerde çalışmalarımı diğer öğrencilerin çalışmaları ile ilişkilendiririm

3. Çevrimiçi derslerde diğer öğrencilerle bilgi alışverişinde bulunurum

4. Çevrimiçi derslerde düşüncelerimi diğer öğrencilerle tartışırım

5. Çevrimiçi derslerde diğer öğrencilerle işbirliği yaparım

\section{Athabasca University $\mathbf{I}$}

(c) (i) 